Please do not remove this page

RMIT

UNIVERSITY

\title{
Maid-in-Singapore: representing and consuming foreign domestic workers in Singapore cinema
}

Gomes, Catherine

https://researchrepository.rmit.edu.au/esploro/outputs/9921858548501341/filesAndLinks?institution=61RMIT_INST\&index=null

Gomes, C. (2011). Maid-in-Singapore: representing and consuming foreign domestic workers in Singapore cinema. Asian Ethnicity, 12(2), 141-154. https://doi.org/10.1080/14631369.2011.571834

Document Version: Accepted Manuscript

Published Version: https://doi.org/10.1080/14631369.2011.571834

Repository homepage: https://researchrepository.rmit.edu.au

(c) 2011 Taylor \& Francis

Downloaded On 2023/04/26 17:16:01 +1000

Please do not remove this page 
Thank you for downloading this document from the RMIT Research Repository.

The RMIT Research Repository is an open access database showcasing the research outputs of RMIT University researchers.

RMIT Research Repository: http://researchbank.rmit.edu.au/

\author{
Citation: \\ Gomes, C 2011, 'Maid-in-Singapore: representing and consuming foreign domestic \\ workers in Singapore cinema', Asian Ethnicity, vol. 12, no. 2, pp. 141-154.
}

See this record in the RMIT Research Repository at:

https://researchbank.rmit.edu.au/view/rmit:14123

Version: Accepted Manuscript

Copyright Statement:

(C) 2011 Taylor \& Francis

Link to Published Version:

http://dx.doi.org/10.1080/14631369.2011.571834 


\section{Maid-in-Singapore: Representing and Consuming Foreign Domestic Workers in Singapore Cinema}

\section{Catherine Gomes}

In 2005, a Singapore horror film narrating the alienation, confusion and fear faced by foreign domestic workers (FDWs) in the island-state entitled The Maid by Kelvin Tong, was released to more than favourable local reception. Filmed in the English, Teochew, Mandarin and Tagalog languages, The Maid became a local box office success, earning SGD\$700,000 in its opening weekend. Made on a shoestring budget of just SGD\$1.5 million, The Maid also won the Asian Award at the 2006 European Fantastic Film Festival Federation for genre and storyline with the jury also noting that The Maid provided 'a social comment on the issue of foreign labour'. ${ }^{1}$ However, the critical audience reviewing the film for English language newsprint dailies and popular entertainment magazines chose not to respond to the film's social commentary on the difficult conditions faced by thousands of FDWs in Singapore. Instead, they wrote extensively on the horror genre and the need for Singapore made films for an audience hungry for local cinema. These reviewers include film writers contributing to Singapore's English language flagship daily The Straits Times, tabloids The New Paper and Today, and weekly entertainment magazine 8 Days. The lack of engagement with the FDW and the issues surrounding her employment and well-being can well be read as revealing certain prejudicial attitudes around ethnicity and class that Singaporean employers and the Singapore government have towards FDWs.

\footnotetext{
${ }^{1}$ This quote can be found in Kelvin Tong's weblog. See Tong, Kelvin Tong, $<$ http://kelvintong.wordpress.com/2008/04/02/kelvin-tong-writerdirector/>. The Maid's critical overseas reception, however, can best be described as lukewarm. It was panned by cross-cultural online critics for its lack of originality within the Asian horror genre. For examples see AnthroFred, 'The Maid',

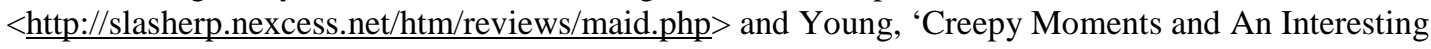
Story', <http://www.movieweb.com/review/REqqitrquTZXuv>.
} 
Art can function as a tool that provides critical commentary of society. Often such social commentary will then be consumed and analysed by the viewing audience. In an essay entitled 'Third World Literature in the Era of Multinational Capitalism' on the incorporation of national allegory in third world texts, Frederic Jameson, amongst other things, implies that art can 'be a political act, with real consequences'. ${ }^{2}$ Art of any culture, regardless of where it comes from, is a creative allegory of the collective society. Art therefore is a powerful signifier of a culture's collective consciousness. Most creative texts, regardless of their national origin contain national allegory of some sort which readers desire to consume. American novels, such as John Steinbeck's The Grapes of Wrath (1939) and F. Scott Fitzgerald's The Great Gatsby (1925) are often labelled and marketed as the 'great American novel'. ${ }^{3}$ These texts are considered canonical texts in American Studies. ${ }^{4}$ Likewise, Hollywood cinema is almost always about American society, regardless of genre. For example, fantasy film genres often provide metaphors for a society's cultural mores. In Tim Burton's Edward Scissorhands, paranoia and suspicion in American society is explored through the relationship artificial man Edward Scissorhands (Johnny Depp) has with a suburban American neighbourhood. The film, set in a 1950s/1990s hybridised era, places Edward, a kind-hearted yet bizarre young man with scissors for hands, in American suburbia. While popular at first, Edward

\footnotetext{
${ }^{2}$ Jameson, 'Third-World Literature in the Era of Multinational Capitalism', 67. This essay is a reprint of an essay Jameson wrote for the third memorial Robert C. Elliot lecture, held at the University of California, San Diego.

${ }^{3}$ Brown, 'The Great American Novel', 1-14.

${ }^{4}$ At a conference I attended not long ago in Pennsylvania on American literature and film, both the literary text and the film adaptation of Grapes of Wrath were still being discussed as necessary texts for the study of American culture. See Lev, 'The Grapes of Wrath and Film Industry Politics'.
} 
becomes the pariah of the town because he looks and behaves differently from the rest of the members of the neighbourhood. ${ }^{5}$

Edward Scissorhands has been described as an eerie echo of Joseph McCarthy's communist witch hunts of the 1950s. ${ }^{6}$ This is especially so when the neighbourhood attempts to destroy Edward at the end of the film. This film thus deconstructs and questions 1950s Hollywood cinema's representation of that era by focusing on the tensions of suburban America. Furthermore it questions earlier Hollywood portrayals of this period as being perfect and innocent, as reflected in film such as Please Don't Eat The Daisies, television programs such as Father Knows Best and the later nostalgia of Happy Days. ${ }^{7}$

One purpose of art therefore is to express a society's political and national concerns. Cultural theorist James Clifford $^{8}$ notes that art is representative of the society it comes from. The role of the reader is to interpret and read politics, society, culture, nation, identity and so on of the community that produced the art. In Hong Kong, for example, people turn to their local cinema for imaginative resolution of matters that plague their society, such as the British handover of Hong Kong to Mainland China in $1997 .{ }^{9}$ Art, in other words, provides evidence of a society's culture.

\footnotetext{
${ }^{5}$ For a synopsis of Edward Scissorshands, see Cooper, 'Edward Scissorshands', $<$ http://www.allmovie.com/work/edward-scissorhands-15350>.

${ }^{6}$ Tanter, 'Return of the B-Movie', <http://www.bbc.co.uk/dna/collective/A3720386>.

${ }^{7}$ Walters, Please Don't Eat The Daisies; Russell and Tewlsbury, Father Knows Best and Marshall et. al., Happy Days.

${ }^{8}$ Clifford, 'On Collecting Art and Culture'.

${ }^{9}$ Bordwell, Planet Hong Kong: Popular Cinema and the Art of Entertainment, 4.
} 
In Singapore art functions as allegories for the nation. Singapore cinema, for instance, often look at the social issues stemming from Singapore's transnational position between Western economy and Eastern traditions. ${ }^{10}$ It is this transitional position that creates a bipolar effect where there is economic progress on the one hand, yet disenfranchisement of the disadvantaged, such as the poor and aged, on the other hand. Films by Eric Khoo (Mee Pok Man, 1996 and 12 Storeys, 1997) and Tan Pin-Pin (Moving House, 2001; Singapore Gaga, 2005 and Invisible City, 2007), in particular, highlight the plight of disenfranchised Singaporeans. The disenfranchised foreigner is also highlighted in the Singapore art scene. ${ }^{11}$

In 2007, The Tales of Three Marias, a groundbreaking play based on the real life experiences of Filipino FDWs - told in a three-part monologue in Filipino with English subtitles - made its debut in a Filipino restaurant in Singapore. In June 2008, the play was staged in a theatre with proceeds going to the Filipino charity Gawad Kalinga. Written, directed and produced by Singapore-based Filipino actor Jay Españo, after extensive interviews with FDWs in Singapore, the play features real Filipino domestic workers in the roles of abused-maid-turned-employer-killer Maria Soledad Padua (Doreen Dangca), veteran maid and single mother Maria Dolores Dimarucut (Nenite de Torres) who questions her ethnic and national identities as she wonders if she is a Filipino or an adopted Singaporean, and Maria Corazon Parungao (Rosa Sarador) who aspires to migrate to the U.S. Through its three Marias, the play reflects on the complex issues of transient migrancy in Singapore such as cross-cultural mis-communication,

\footnotetext{
${ }^{10}$ Marchetti, 'Global Modernity, Postmodern Singapore and the Cinema of Eric Khoo'.

${ }^{11}$ Ibid, 330.
} 
class hierarchy, racism, human rights violations, victimisation, identities of self complicated by space and place, displacement and globalisation. The Tales of Three Marias features Singapore as the unseen yet omnipresent spectre that affects them profoundly both professionally and personally.

While The Tales of Three Marias also documents experiences of a community which are not racially, ethnically and culturally similar to any of the major groups - Indian, Chinese and Malay — in multiracial Singapore, some of the play’s themes run parallel to experiences early transients and settlers faced at the hands of colonists in Singapore such racism and class hierarchy. Likewise, other themes connected to the complexities of identity are similar to those experienced by Singaporean citizens. Singaporeans are themselves mostly descendants of settlers from the region or themselves first generation migrants who settled prior to Singapore’s independence in 1965. The Singaporean arts scene, the media and online communities often attempt to make sense of national and cultural identity in this plural society.

The play is perhaps an authentic representation of the Filipino domestic worker since it documents the cross-cultural work experiences of self and identity of real maids, its accessibility however was regulated by language and limited number of performances. Although the play was critically well received within the Filipino community in Singapore, with plans to take it to the Philippines, it has, to date, only had two public performances. 
Not limited to local theatre, FDWs are also featured in Singapore-made films such as Gone Shopping and Singapore Dreaming. ${ }^{12}$ Unlike the Filipino-centred and communityauthored maid experiences depicted in The Three Marias, FDWs are mostly portrayed as fringe characters who frame supporting or principal characters. In Gone Shopping, the domestic worker is a young Indonesian woman in the employment of a wealthy and unpleasant woman (Selena Tan) whose presence enhances the woman's privileged position. However, in Singapore Dreaming the domestic worker Pinky (Mariel Reyes) has a stronger presence in the film. She is a pleasant and obedient Filipino maid who loses her temper when accused of theft by Mrs Mei Teo (Yeo Yann Yann), a principal character in the film. Defending herself, Pinky shows her disgust with her employer Mrs Teo and spits at her after being vindicated of the crime. Pinky's reaction plays a pivotal role in the film leading Mrs Teo on a journey of self-discovery and self-frustration. Both these films portray foreign maids as minor characters, thus successfully replicating the secondary position of FDWs in Singapore society. They also reveal that FDWs are an accessible commodity for the wealthy (Gone Shopping) and the working class (Singapore Dreaming). While Gone Shopping and Singapore Dreaming present FDWs as minor characters, the 2005 film The Maid became the first and only locally made-production to date to feature a domestic worker as its protagonist.

Singapore-made horror film The Maid narrates the story of Rosa Dimaano (Alessandra de Rosi), an 18 year old Filipino girl who enters Singapore for the first time as a domestic worker in the service of Mr and Mrs Teo, a local middle-aged couple (Chen Shu Cheng and Hong Hui Fang) and their autistic adult son Ah Soon (Benny Soh). The

\footnotetext{
${ }^{12}$ Wee, Gone Shopping; and Goh and Woo, Singapore Dreaming.
} 
day that she arrives marks the first day of the Yu Lan Festival, popularly known as the Hungry Ghost Festival and the Chinese Seventh Month Festival. The Hungry Ghost Festival is a month-long Chinese pagan festival dedicated to the worship of the dead. It is during this yearly festival that the gates of hell are believed to be flung open and the dead walk amongst the living. To appease the dead and therefore discourage them from harming the living, and thus provide the assurance of peace and prosperity, believers nourish the ghosts by leaving food for them on the street, giving them offerings by regularly burning fake notes in barrels and entertaining them by staging open-air live Chinese opera shows. ${ }^{13} \mathrm{Mr}$ and Mrs Teo are heavily involved in the Hungry Ghost Festival festivities as they are Chinese street opera performers.

Rosa initially gets along well with the Teos. Mr and Mrs Teo treat her well and Rosa develops a genuine affection for Ah Soon. However, Rosa is continually haunted by the presence of a multitude of ghosts after breaking several taboos relating to the Hungry Ghost Festival. These include verbalising the word 'ghost', sweeping away the ash from burnt offerings and sitting in the front row of seats, normally reserved for supernatural audiences, of a Chinese street opera performance. One of the ghosts whom Rosa encounters is the Teos' former Filipino maid Esther Santos. Esther was killed exactly a year earlier by Mr and Mrs Teo to prevent her from reporting her rape at the hands of Ah Soon. In a dramatic twist towards the end of the film, Rosa discovers that Ah Soon killed himself soon after finding out about Esther's death. Ah Soon was an apparition that only appeared to Rosa and the Teos. The Teos attempt to kill Rosa in order for her to marry

\footnotetext{
${ }^{13}$ For a concise description of the Hungry Ghost Festival, see see Lee, 'Professional Chinese Opera Troupes and Street Opera Performance in Singapore’, 35-70.
} 
Ah Soon in death. It is however Ah Soon's ghost who saves Rosa. This results in the deaths of Mr and Mrs Teo. In the film's final moments, Rosa is dropped off at the airport where she is about to leave for the Philippines, coincidentally the final day of the Hungry Ghost Festival. She takes with her Esther's remains which she earlier discovered stuffed in a barrel at the Teos. The film ends with the Rosa entering the airport and the reflection of the ghosts of the dead Teos on the sliding glass doors.

Filmmaker Kelvin Tong states in interviews that the purpose of the narrative in The Maid is to represent the plight of domestic workers in Singapore. His use of the horror genre can be interpreted as representing the 'horror' of alienation and unexpected dangers faced by FDWs upon entering an unfamiliar country with unfamiliar languages and a seemingly macabre culture that publicly worships the dead for a month every year. As a signifier of FDWs in Singapore, Rosa in an Other as her foreignness is emphasised through nationality, ethnicity, culture and language. As a foreign Other, her stay in Singapore is a limited sojourn. The only way she is able to blend in with the cultural landscape is through a combined process of a ritualistic (and illegal) marriage and (unlawful) death. ${ }^{14}$ With marriage, her Filipino identity would be erased as she will have to take on the family name of her husband. In death, the erasure of her foreign identity would be completely erased as she would not be a living reminder of her Filipino heritage. Perhaps this could explain why at the end of the film Rosa returns to the

\footnotetext{
${ }^{14}$ Marriage to FDWs in Singapore, as I point out later in this paper, is illegal.
} 
Philippines with the remains of the murdered Esther. Death alone does not make the transformation from foreign to local complete. ${ }^{15}$

Although Tong advocated the plight of domestic workers in Singapore, the critical audience all but ignored the subject of foreign domestic service. Instead, reviewers in the local press chose to comment on the production quality of The Maid, Tong's film credentials and the popularity of local cinema amongst Singaporean audiences. Sherwin Loh and Ong Sor Fern of The Straits Times both comment on the contributions made by The Maid as a product of the home grown entertainment industry in their reviews of the film. Jeanine Tan of Today (1 September, 2000) further examines The Maid's potential for promoting Singapore's film industry to the international limelight as a Hollywood remake in her report entitled 'Brad Pitt Eyes The Maid'. The local film industry is further commented upon in articles on filmmaker Kelvin Tong’s filmmaking career by Tommy Wee of 8 Days $^{16}$ and an anonymous writer for The New Paper (1 August 2005). The central theme by all these film writers however is their discussion on the Hungry Ghost Festival as the driving force of the film’s horror element.

Like the wider audience, the film writer recognises signs and symbols, and codes and conventions in a film. However, the critic's job is to comment on films in the public

\footnotetext{
${ }^{15}$ The Maid, however, does temper the FDW experience in Singapore when compared to the play The Three Marias. While her employers turn out to be the villains of the piece, murdering their previous Filipino maid and attempting to kill Rosa, their actions are not based on master-servant hierarchies. Throughout the film, the Teos treat Rosa as they would their own daughter, if they had one. Their intention to kill Rosa is to make her the ghost bride of their dead son. While macabre, they see her as the ideal or only candidate to make their son happy in death, while fulfilling their own desire to see him married. Rosa, however, is not the victim of overt racial or class prejudices. The Maid's presentation of Rosa's domestic worker status in Singapore, in other words, does not parallel the experiences of FDWs in Singapore.

${ }^{16}$ Wee, 'Director's Cut', (n.p).
} 
domain. Martin Barker and Thomas Austin, for example, write that a film critic is a person 'who can place a film in a tradition for you, who will tell you about the director, the cinematography, the special effects'. ${ }^{17}$ Besides analysing films, the film critic, they continue, 'will point you to continuities, and offer a sense of the significance of a particular film'. ${ }^{18}$ Dugald Williamson further defines the critic as a person who 'performs a certain kind of work on the text, spelling out thematic, narrative, characterological or stylistic patterns, and then treats these as manifestations of some prior creative purpose'. ${ }^{19}$ Williamson also notes that the 'effects of meaning produced by using particular techniques of reading and writing are retroactively attributed to an individual origin: this is how author criticism generates textual evidence for the idea of individual vision'. ${ }^{20}$ In his interpretation of the relationship between critic and text, Williamson explains that the critic's role is to 'tell a secret about the art-work, to tease out what the latter does not say for itself, yet to preserve and pore over the precise form of the original words or images which is seen as fraught with meaning' ${ }^{21}$ Williamson also points out that the critic can say something new about the work being critiqued. ${ }^{22}$

The critical audience thus is attracted to the film's place in Singapore's burgeoning film industry. A possible reason for local reviewers' interest in examining The Maid within the lens of the Singapore film industry lies in the growing popularity of credible local productions that depict familiar aspects of Singapore culture and identity.

\footnotetext{
${ }^{17}$ Barker and Austin, From Antz to Titanic: Reinventing Film Analysis, 1.

${ }^{18}$ Ibid.

${ }^{19}$ Williamson, Authorship and Criticism, 46.

${ }^{20}$ Ibid.

${ }^{21}$ Ibid, 47.

${ }^{22}$ Ibid, 49.
} 
Singaporean filmmakers thus make use of local audiences' desire for local flavour in their cinema. In The Maid, the devices that allow local audiences to recognise and identify Singapore culture and identity take the form of the Hungry Ghost Festival and the street opera.

In his extensive study on Chinese street opera, for example, Lee Tong Soon argues strongly that this form of performance contributes to Singapore's national identity. ${ }^{23}$ While displays of culture were once considered either private or community concerns in the post-independence era, the 1980s witnessed the state beginning to place emphasis on cultural heritage. ${ }^{24}$ Explaining the state's change of approach to community heritage, treating it now as a tenet of Singapore nationalism, Lee states:

[T]he process of cultural nationalism intensified, which evoked issues of ethnic lineage, linguistic uniqueness, religious beliefs and fold traditions among other social practices to affirm a collective national identity. Such a form of nationalism was deemed necessary to counter the perceived negative effects of Westernisation and rapid economic success that had characterised Singapore's growth, such as materialistic orientation, consumerism, political liberalism and individualism, to name a few. Art and cultural programs were instituted to salvage, invent and reinvent local cultures, reaffirm local values, construct a Singaporean and pan-Asian identities, and to align Singapore with the ongoing processes of modernisation and globalisation. In this way, Chinese street opera became an appropriate symbol for the cultural ideal of possessing a strong

${ }^{23}$ Lee, 'Chinese Street Opera Performance and the Shaping of Cultural Aesthetics in Contemporary Singapore’, 139-61.

${ }^{24}$ Ibid, 150. 
heritage in a rapidly modernising social space because it embodied the imagery of a rural, simple and rustic local tradition. ${ }^{25}$

The Chinese street opera thus is a social phenomenon which 'is probably the most representative local heritage in Singapore'. ${ }^{26}$ Chinese opera performances present more than just 'artistic achievement but an indication of the state of cultural anxiety that has confronted (and continues to challenge) Singapore since its independence in $1965{ }^{2}{ }^{27}$ This 'aesthetic framework', Lee clarifies, 'structures the meanings and values of a Singaporean form of cultural nationalism in its pursuit of national and cosmopolitan identities’. ${ }^{28}$

The critical audience is an insightful analytical tool when examining a society's attitudes toward any given subject. According to Judith Mayne, ${ }^{29}$ the film commentator has prior knowledge of films within the genre, cast, crew and filmmakers s/he is commenting upon. However, the film commentator also comes with certain methodologies and ideologies which s/he looks for. In other words, the film reviewer not only has specialist knowledge in film but more importantly, uses his/her experiences to approach and respond to a film. Mayne provides the example of herself as a film

\footnotetext{
${ }^{25}$ Ibid.

${ }^{26}$ Ibid, 141. Chinese opera is a traditional form of entertainment whose importance in Chinese culture is traced back to the third century $\mathrm{AD}$, often performed amongst the Chinese diaspora in Mandarin or Cantonese. Chinese opera heavily influenced the development of Chinese cinema in the early twentieth century but underwent a purging during the Cultural Revolution.

${ }^{27}$ Lee, 'Chinese Street Opera Performance and the Shaping of Cultural Aesthetics in Contemporary Singapore’, 140.

${ }^{28}$ Ibid.

${ }^{29}$ Mayne, Cinema and Spectatorship, 157-8.
} 
commentator or critic, by highlighting her sexuality. She states that because she is queer, she negotiates a film from a queer perspective.

Hence the lack of local media critical engagement with the film’s social commentary however is a significant signifier of Singaporean attitudes towards FDWs. While the FDW is 'invisible' to the Singaporean critical audience who watched the film, she is, ironically, a very visible demographic entity in Singapore. The FDW's invisibility in the film is perhaps linked to her treatment by both the Singaporean employer and the Singapore government. Such treatment reveals certain prejudicial attitudes based on ethnicity and class Singapore society holds towards transient migrants who enter this wealthy city-state in droves as domestic servants.

\section{The Foreign Domestic Worker in Singapore: Employer Dissatisfaction and Government Policies}

Singapore is a transnational and transitional space which invites temporary or transient migrants, particularly unskilled labourers and domestic servants attracted to the work available. The entrance of recent permanent and transient migrants, predominantly from other Asian nations, has been a cause for concern amongst Singaporean citizens who either settled in pre-independence Singapore or who trace their lineage to settlers who arrived when the nation was still a British colony. ${ }^{30}$ Post-independence migrants

\footnotetext{
${ }^{30}$ Discussions in online forums such as those in Asiaone.com and entries in personal weblogs often raise the issue of foreigners in Singapore. Towards the later -half of 2008, for example, the issuing of Singapore permanent residence to Chinese nationals who took part in the Beijing Olympics and the government's plan to create dormitories for unskilled foreign labourers in an upper-middle class neighbourhood became hot topics amongst netizens. Many who aired their opinions on the issuing of permanent residence to the China-born athletes took an anti-foreign stand while crusading for a 'pure' Singapore society. Those who commented on the housing of unskilled foreign workers debated on the civil action the residents of the
} 
pose a kind of trauma for the citizenry, perhaps caused by Singapore's uneven immigration policy trends between 1965 to the late 1970s.

The FDW, for instance, started entering Singapore in the early 1980s when the nation-state turned to its regional neighbours for a steady supply of maids to take over the household duties of local women who were joining the workforce in increasing numbers. These transient female migrants often came from developing Asian nations such as the Philippines and Indonesia, with growing numbers coming from Sri Lanka, Myanmar and elsewhere. Today, FDWs have become a common feature in Singaporean households with one in eight families employing a migrant domestic worker. ${ }^{31}$ Current employment practices of FDWs in Singapore reveal certain social tensions between local employer and transient migrant worker. ${ }^{32}$ Often, these social tensions are expressed through patronising and negative comments by local employers. Most often, employers engage in informal verbal discussions with each other; airing their personal yet problematic encounters with domestic help or providing general observations on FDW collective work practices. ${ }^{33}$

Some Singaporeans have turned to virtual public forums and databases to air their grievances about FDWs, to seek or provide advice on employment practices; thereby

neighbourhood took to prevent this government initiative and the broader debate of Singapore's reliance on both unskilled and skilled foreign labour.

${ }^{31}$ Ong, Neoliberalism as Exception: Mutations in Citizenship and Sovereignty, 195-298.

32 Ibid; Yeoh, Huang and Gonzalez, 'Migrant Female Domestic Workers', 141-36; Rahman, 'Shaping the Migrant Institution', 182-216; Kaur, 'International Labour Migration in Southeast Asia', <http://wwwsshe.murdoch.edu.au/intersections/issue15/kaur.htm>and Ford and Piper, 'Southern Sites of Female Agency', 1-24.

33 These comments reveal the employment practices of FDWs at the hands of their employers is akin to neo-slavery, with scholarship in the area of transient migrant female workers supporting this observation (for example Ong, Neoliberalism as Exception: Mutations in Citizenship and Sovereignty, 195-298). 
forming online employer communities. Often the Singaporean employers name the country of origin of the FDWs, therefore implying alleged links between perceived bad work practices and nationality. Internet websites dedicated to employer concerns such as Maidlibrary (http://www.maidlibrary.com.sg/) and Bad Maid Database (http://badmaid.scaat.net/index.shtml) unveil a disturbing yet consistent trend of disdain towards FDWs, highlighting tension in the employment practices of FDWs. Such practices draw attention to the curtailment of individual freedom particularly highlighted through the surveillance of FDWs by employers and the practice of not according them local civil rights. Posts in The Maid Library and Bad Maid Database reveal that employers expect FDWs to be in constant service during waking hours as breaks are interpreted negatively as laziness. In addition, contributors to these forum sites require FDWs to behave within a certain master-servant framework emphasising subservience and obedience to employers. Any deviation from this framework promotes the ire of the employers. The contempt many Singaporean employers seem to express for their FDWs occurs even as the Singapore government currently engages in an education campaign on the fair treatment of FDWs. ${ }^{34}$

\section{The Maid Library and Bad Maid Database}

The Maid Library, describes itself as a 'business dedicated to maid and home-help related services...[which...seek[s] to provide a convenient channel for employers to browse and select maid biodata'. The website seems to have a dual purpose: functioning as an online search engine for FDWs and as a virtual community of Singaporean

\footnotetext{
${ }^{34}$ For example, the Ministry of Manpower publishes literature (print and online copies) for employers on the fair treatment of FDWs such as Foreign Domestic Worker Employers Handbook in English, Mandarin, Malay and Tamil.
} 
employers to air their grievances about their migrant domestic helpers under the heading 'Community'. The table below shows a breakdown of the threads and posts of each forum in 'Community'. The purpose of the subdivisions is reproduced in verbatim.

\begin{tabular}{|c|c|c|c|c|}
\hline & List of Forums & Threads & Posts & $\begin{array}{l}\text { Last } \\
\text { Posts } \\
\text { as of } \\
\text { Jun } 19 \\
2008 \\
8: 38 \\
\text { am } \\
\end{array}$ \\
\hline & ASSOCIATION & & & \\
\hline A & $\begin{array}{l}\text { United Employers Voice } \\
\text { This forum seeks to address pertinent issues in the } \\
\text { interests of a united voice for maid employers in } \\
\text { Singapore. }\end{array}$ & 45 & 398 & $\begin{array}{l}\text { Sept } 21 \\
2007 \\
1: 45 \mathrm{pm}\end{array}$ \\
\hline B & $\begin{array}{l}\text { Employers, maids \& M.O.M (Ministry of } \\
\text { Manpower) } \\
\text { What goes beyond fair domestic duties. Views to air } \\
\text { with MOM on maid issues, levies and miscellaneous } \\
\text { queries. Do post them here. }\end{array}$ & 44 & 428 & $\begin{array}{l}\text { Apr } 4 \\
2008 \\
7: 17 \text { am }\end{array}$ \\
\hline C & $\begin{array}{l}\text { Maid Agencies - Could be better } \\
\text { A fully-moderated forum: posts would be assessed } \\
\text { and may be edited for public display suitability. } \\
\text { Your posts help the Association chart a future course } \\
\text { of action in encouraging better maid agency practices } \\
\text { whether by mediation, or by making your feedback } \\
\text { known to the agencies or other employers. We also } \\
\text { welcome private posts meant for our filing and action } \\
\text { instead of publishing. }\end{array}$ & 2 & 12 & $\begin{array}{l}\text { Apr } 3 \\
2006 \\
10: 54 \\
\text { pm }\end{array}$ \\
\hline & GENERAL DISCUSSION & & & \\
\hline D & $\begin{array}{l}\text { Latest Contributions } \\
\text { Share anything. The good and the bad. Note: No } \\
\text { posts requesting or recommending maid agencies are } \\
\text { allowed. }\end{array}$ & 384 & 3617 & $\begin{array}{l}\text { Jun } 14 \\
2008 \\
11: 50 \\
\text { am }\end{array}$ \\
\hline E & $\begin{array}{l}\text { Starting off, choosing a maid } \\
\text { The basics and a touch of the finances involved. } \\
\text { Broad categories in maid selection. }\end{array}$ & 84 & 828 & $\begin{array}{l}\text { Apr } 4 \\
2008 \\
9: 29 \mathrm{pm}\end{array}$ \\
\hline $\mathbf{F}$ & $\begin{array}{l}\text { Baby \& child } \\
\text { Many start employing maids from this time. }\end{array}$ & 28 & 357 & $\begin{array}{l}\text { Jun } 18 \\
2008\end{array}$ \\
\hline
\end{tabular}




\begin{tabular}{|l|l|l|l|l|}
\hline G & \multicolumn{1}{|c|}{$\begin{array}{l}\text { Life with maid - adjustments, concerns, problems } \\
\text { Undeniably most life-consuming, day-in and day-out. } \\
\text { Realities to get acquainted with. }\end{array}$} & 63 & 807 & $\begin{array}{l}\text { Jun } 16 \\
2008 \\
11: 12 \\
\text { am }\end{array}$ \\
\hline $\mathbf{H}$ & $\begin{array}{l}\text { Be fair to your maid but still in control } \\
\text { What is fair to bestow to your maid? How much } \\
\text { control should you rein? Calibrate it here with other } \\
\text { employers. }\end{array}$ & 48 & 724 & $\begin{array}{l}\text { Apr } \\
2008 \\
09: 39\end{array}$ \\
\hline $\mathbf{I}$ & $\begin{array}{l}\text { Wayward at home and out } \\
\text { It takes two whether at home or not. }\end{array}$ & 19 & 319 & $\begin{array}{l}\text { Mar } 30 \\
2007 \\
01: 04 \\
\text { pm }\end{array}$ \\
\hline $\mathbf{J}$ & Blacklisted Maids & 87 & 1158 & $\begin{array}{l}\text { Jun } 13 \\
2008 \\
1: 40 \text { pm }\end{array}$ \\
\hline
\end{tabular}

Table 1. List of forums in 'Community'

The above table provides some insight into the discussion activities of users of this particular service of The Maid Library. The list of forums are categorised into two groups: association and general discussion. The association deals with issues pertaining, although not limited to organisations in Singapore handling FDWs such as the Ministry of Manpower, the government department that regulates FDW employment in Singapore and maid agencies. While employment practices of FDWs are discussed under the general discussion heading, such issues are also brought up under association. The 'Community' has a variety of forums on specific aspects of FDW employment practices; with some of the initial posts taking place as early as 2000 (B, D, E, F and H). While some of the forums have been dormant at the time this paper was written (A, C and I), others are still active (B, D, E, F, G, H and J). Some of the forums experience more traffic (for example D, E and J) than others (for example C). As of 19 June 2008, there were 1787 registered uses for the forums on The Maid Library. Users who contribute to 
the forums have their identities concealed by psudonyms. There are a few users, however, who seem to use their real names. Unfortunately there is no way of verifying if this. All users in these forums appear mainly to be employers or potential employers with a very limited number who claim to be potential FDWs looking for employment.

The primary purpose of this forum seems to serve as a database for blacklisting maid agencies and maids. The Maid Library collects this data from the input of its registered users. The criteria for the listing of 'bad' maid agencies are: a) the recommendation of 'bad' maids and b) maid agencies' refusal to exchange or provide refunds for 'bad' maids. Often, 'bad' maids in this forum are defined as lazy workers who do not do as they are told by employers. There are a few posts in United Employers Voice that advocate for an association of employers that protects the rights of employers against 'bad' maids and 'bad' maid agencies.

The Maid Library community forums do allow for discussions on migrant workers who behave well. Good behaviour primarily means quietly obeying their employers' instructions to the letter. Any resistance is punished through verbal reprimands or the withdrawal of certain privileges, often related to mobile telecommunication. In other words, only when maids adhere to a master-servant hierarchy, will they then be considered 'good'. Most of the posts in the forum discuss employer difficulties with their FDWs with some recurring themes. These include accusations of FDWs allegedly lying to their employers, theft, laziness, gluttony, personal hygiene and appearance, running away, child abuse, possessing mobile phones, socialising with other FDWs in the 
neighbourhood and in clandestine relationships with men, often unskilled expatriate labourers. Some topics in these forums include:

'Tips on training a new maid'

'Body Odour?'

'Superstitions / Black Magic'

'employer's woe’

'stubborn or dont understand?'

'Maid who tell lies'

'Maid too forgetful or otherwise dont understand'

'Maid using water heater'

'Attitude maid'

'maid sleeping topless'

Unless blacklisting their maids, employers using The Maid Library as a forum, do not refer to their FDWs by name. Instead, they otherise their employees often by referring to them as 'girl'. More of a concern in forum discussions, however, is the open practice and encouragement of employment practices that maintain FDWs as inmates while in local employment, to constantly monitored by their employers. The posts expose an imagined and desperate need to control the FDWs both professionally and personally as employers equate the personal lives of maids as affecting their professional service. A masterservant hierarchy, thus, is maintained. 
FDWs have encountered tension with their host country's citizens. In her work on Filipino FDWs in 1990s Hong Kong, Nicole Constable ${ }^{35}$ points out that there are feelings of dislike for Filipino maids by Hong Kong inhabitants particularly with regard to public space. Here Constable provides the example of the weekly Sunday closures of Charter Road by the Hong Kong authorities so as to enable Filipinos to gather in an enclosed space. This act has generated widespread feelings of discontent among Hong Kong people as they feel FDWs are accorded more rights than Hong Kong people themselves. Feelings of dislike for FDWs in Singapore, however, can be interpreted as directly rather than indirectly aided by the government. The Singapore government has very strict policies in place when it comes to managing the FDWs' sojourn in the island state.

FDWs are considered transient migrants in Singapore whose employment is determined by a special visa known as a work permit which is subject to renewal biannually by the Ministry of Manpower. Work permit holders are not eligible for permanent residence. They usually have their activities curtailed and are under surveillance. For instance, FDWs have to undergo twice yearly sexual health and pregnancy checks. Failing either of these, they are repatriated within seven days of the cancellation of their work permit. They are not allowed to marry Singapore citizens or permanent residents unless granted permission by the Controller of Work Passes. According to the Fourth Schedule, Conditions of Work Permit/Visit Pass for Foreign Worker in Employment of Foreign Manpower Act (Chapter 91A), FDWs are also forbidden by law to 'be involved in any legal, immoral or undesirable activities,

\footnotetext{
${ }^{35}$ Constable, Maid to Order in Hong Kong: Stories of Filipino Workers, 1-12.
} 
including breaking up families in Singapore' ${ }^{36}$ The Singapore government's strict policies surrounding FDWs in some ways may serve to promote distrust of these women amongst Singaporean employers.

\section{Conclusion}

When the Singapore made film The Maid was released locally, the production generated a favourable response from audiences within the general film-viewing public and reviewers who wrote for the English language dailies. While the film narrated the plight of FDWs in Singapore, the critical audience choose to ignore the social issues surrounding domestic workers in Singapore. The lack of commentary by the critical audience in the Singapore media, however, can be read as expressing the multilayered consumption of the image of the foreign domestic as an ethnic Other, thus revealing certain tensions Singaporeans have towards FDWs which are displayed openly in online forums patronised by Singaporean employers and assisted by the government's strict policies governing foreign domestic service. The professional relationship between local employers in Singapore and their transient migrant female workers reveals a type of master-servant relationship present in current employment practices of FDWs. This master-servant relationship exposes the active existence of a complex class hierarchy that has nationalist overtones. While Singapore is a multiracial society primarily made up of Chinese, Indian and Malay ethnicities whose citizens are able to trace their lineage to the early settlers of colonial Singapore, the government has successfully put in place policies that unify its people under a nationalist umbrella which promotes allegiance to the state

\footnotetext{
${ }^{36}$ See 'Work Pass', Ministry of Manpower, <http://www.mom.gov.sg/publish/momportal/en/communities/work_pass.html>.
} 
and national pride. An avenue the government relies on to create Singaporean nationalism involves imagining Singapore, its society and its government-sponsored achievements in a favourable light when compared to other nations and their achievements, particularly around general elections time. The result is a situation where recent and particularly transient migrants outside this racial and historical template may be interpreted as posing a threat to Singapore's present multiracial palate. The openly expressed tensions that ostracise the FDW within ethnic and class based frameworks may well signify a subliminal form of local nationalism that places Singapore above its poorer Asian neighbours in capitalist lifestyle and development. 


\section{Bibliography}

Anon. 'Kelvin Tong Returns with The Maid'. The New Paper, 1 August 2005, (17).

AnthroFred. 'The Maid', Slasherpool.com.

<http://slasherp.nexcess.net/htm/reviews/maid.php> (accessed 8 September 2008).

Bad Maid Database (n.d.). <http://badmaid.scaat.net/index.shtml>.

Barker, Martin with Thomas Austin. From Antz to Titanic: Reinventing Film Analysis. London and Sterling, VA: Pluto Press, 2000.

Bordwell, David. Planet Hong Kong: Popular Cinema and the Art of Entertainment. Cambridge, Mass and London, England: Harvard University Press, 2000.

Brown, Herbert R. 'The Great American Novel', American Literature 7 (1935): 1-14.

Clifford, James. 'On Collecting Art and Culture' in The Predicament of Culture:

Twentieth-century Ethnography, Literature, and Art. Cambridge, Mass.: Harvard University Press, 1988.

Constable, Nicole. Maid to Order in Hong Kong: Stories of Filipino Workers. New York: Cornell University Press, 1997.

Cooper ,Tracie. 'Edward Scissorshands'. All Movie Guide (n.d.).

http://www.allmovie.com/work/edward-scissorhands-15350 (accessed 6 April 2010).

Ford, Michelle and Nicola Piper. 'Southern Sites of Female Agency: Informal Regimes and Female Migrant Labour Resistance in East and Southeast Asia'. Southeast Asia Research Centre Working Paper Series 82 (2006): 1-24.

Hakari, Adam. 'Respect your Elders - or Else!' ReelTalk Movie Reviews (2008). $<$ http://www.reeltalkreviews.com/browse/viewitem.asp?type=review\&id=1861/>, (accessed 8 September 2008).

Jameson, Fredric. 'Third-World Literature in the Era of Multinational Capitalism'.Social Text 15 (1986): 65-88.

Kaur, Amarjit. 'International Labour Migration in Southeast Asia: Governance of Migration and Women Domestic Workers', Intersections. 15 (2007), $<$ http://wwwsshe.murdoch.edu.au/intersections/issue15/kaur.htm> (accessed 2 July 2007).

Lee Tong Soon. 'Professional Chinese Opera Troupes and Street Opera Performance in Singapore’. Asian Music 31, no. 2 (Spring - Summer, 2000): 35-70. 
. 'Chinese Street Opera Performance and the Shaping of Cultural Aesthetics in Contemporary Singapore.’ Yearbook for Traditional Music 34 (2002): 139-61.

Loh, Sherwin. 'Maid for Movies’. The Straits Times, 5 August 2005, (Life Buzz) . 'Red Scare'. The Straits Times, 9 August 2005, (Life Buzz)

Lev, Peter. 'The Grapes of Wrath and Film Industry Politics'. Paper presented at the Cinema/Cinemas Conference organised by the Literature/Film Association, 13-16 October 2005.

Maidlibrary (n.d.). <http://www.maidlibrary.com.sg/>.

Marchetti, Gina. 'Global Modernity, Postmodern Singapore and the Cinema of Eric Khoo’. In Chinese-Language Film: Historiography, Poetics, Politic. Ed. Sheldon Hsiaopeng Lu and Emilie Yueh-Yu Yeh. Honolulu: University of Hawai’i Press, 2005.

Mayne, Judith. Cinema and Spectatorship. Edited by Edward Buscombe and Philip Rosen. London and New York: Routledge, 1993.

Ministry of Manpower. 'Work Pass’. Ministry of Manpower: Virtual Centre for Your Manpower Needs, <http://www.mom.gov.sg/publish/momportal/en/communities/work_pass.html> (accessed 4 December 2008).

Ong, Aihwa. Neoliberalism as Exception: Mutations in Citizenship and Sovereignty. Durham; London: Duke University Press, 2006.

Ong, Sor Fern. 'Reel Deal'. The Straits Times, n.d, (Life Movies).

Rahman, Noor Abdul. 'Shaping the Migrant Institution: The Agency of Indonesian Domestic Workers in Singapore’. In The Agency of Women in Asia, ed. Lynn Parker. Singapore: Marshall Cavendish Academic, 2005.

Steinbeck, John. The Grapes of Wrath. New York: Viking Press, 1939.

Tan, Jeanine. 'Brad Pitt Eyes The Maid'. Today, 1 September, (n.p).

Tranter, Rhys. 'Return of the B-Movie', BBC Collective, 26 February, 2006, $<$ http://www.bbc.co.uk/dna/collective/A3720386>.

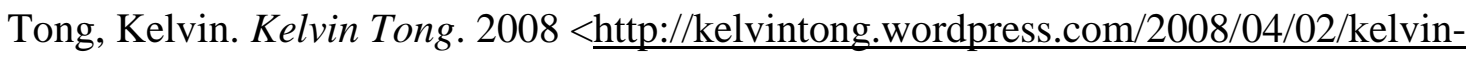
tong-writerdirector/> (accessed 26 June 2006).

Wee, Tommy. 'Director’s Cut'. 8 Days, 25 August 2005, (n.p). 
Williamson, Dugald. Authorship and Criticism. Sydney: Local Consumption Publications, 1989.

Yeoh, Brenda, Shirlina Huang and Joaquin Gonzalez. 'Migrant Female Domestic Workers: Debating the Economic, Social and Political Impacts in Singapore'. International Migration Review 33, no. 1 (1999): 141-36.

Young, Travis. 'Creepy Moments and An Interesting Story'. Movieweb: The Best Seat in the House. 2005. <http://www.movieweb.com/review/REqqitrquTZXuv>, (accessed 8 September 2008).

\section{Filmography}

12 Storeys/Shier Lou. Dir. Eric Khoo. Singapore: Bring Creative, Springroll Entertainment and Zhao Wei Films, Singapore. 1997.

Edward Scissorhands. Dir. Tim Burton. Hollywood: 20 ${ }^{\text {th }}$ Century Fox, 1990.

Father Knows Best. Dir. William D. Russell and Peter Tewlsbury. Hollywood: American Broadcasting Company, Columbia Broadcasting System, National Broadcasting Company, Rodney-Young Productions, Screen Gems Television, 1954-60.

Gone Shopping. Dir Wee Li Lin. Singapore: Kismet Films, 2007.

Happy Days. Dir. Gary Marshall et. al. Hollywood: American Broadcasting Company, Henderson Production Company, Miller-Milkis Productions, Miller-Milkis-Boyett Productions, Paramount Television, 1974-84.

Invisible City. Dir. Tan Pin-Pin. Singapore: Objectifs Films, 2007.

Mee Pok Man. Dir. Eric Khoo. Singapore: 27 Productions, Singapore, 1995.

Moving House. Dir Tan Pin-Pin. Singapre: Objectifs Films, 2001.

Please Don't Eat The Daisies. dir. Charles Walters. Hollywood: Metro-Goldwyn-Mayer, Euterpe Inc., 1960.

The Maid/Kimyo Na Sakasu. Dir. Kelvin Tong. Singapore: Dream Movie Entertainment Ltd., Media Development Authority, Mediacorp Raintree Pictures and Mov-Pix International Pictures, 2005.

Singapore Dreaming/Mei Man Ren Sheng. Dir. Colin Goh and Woo Yen Yen. Singapore: Golden Village Entertainment, 2006.

Singapore Gaga 2005, Objectifs Films, Singapore. 


\section{Plays}

The Tales of Three Marias, writer, prod. and dir. Jay Españo, 2007. 